\title{
First record of Spurilla neapolitana (Mollusca: Nudibranchia: Aeolidiidae) on the central coast of Peru (Humboldt Current Upwelling Ecosystem)
}

\author{
ROBERTO A. URIBE ${ }^{1}$ AND ALDO S. PACHECO ${ }^{2}$ \\ ${ }^{1}$ Programa de Doctorado en Ciencias Aplicadas Mención Sistemas Marinos Costeros, Universidad de Antofagasta, Avenida \\ Angamos 601, PO Box 170, Antofagasta, Chile, ${ }^{2}$ Instituto de Investigaciones Oceanológicas, Universidad de Antofagasta, \\ Antofagasta, Chile
}

\begin{abstract}
Members of the genus Spurilla are nudibranchs with circumtropical distribution. Spurilla neapolitana is reported for the first time inhabiting subtidal soft-bottom habitats of the central coast of Peru. Adult specimens were found in Bahía Ferrol $\left(09^{\circ} 04^{\prime} \mathrm{S} 78^{\circ} 35^{\prime} \mathrm{W}\right)$ at $10 \mathrm{~m}$ depth in November of 2009. Spurilla neapolitana is characterized by the presence of a long body with numerous cerata along the dorsal side of the body and a distinctive orange colouring with white dots. This finding extends the geographical range of Spurilla spp. into the south-eastern Pacific and adds a new contribution to the macro-mollusc diversity thriving in the Humboldt Current Upwelling Ecosystem.
\end{abstract}

Keywords: nudibranchs, range extension, Bahía Ferrol, Ancash, sea slug

Submitted 3 September 2011; accepted 22 November 2011

\section{INTRDDUCTION}

The northern area of the Humboldt Current Upwelling Ecosystem (HCUE) in front of the Peruvian coast $\left(3^{\circ} 23^{\prime}-\right.$ $10^{\circ} 21^{\prime} \mathrm{S}$ : Chavez et al., 2008) holds a unique marine biodiversity due to the spatial heterogeneity of the coastline and the complex oceanographic characteristics, especially the oscillating conditions produced by the occurrence of the warm El Niño and cold La Niña events (Paredes et al., 1998, 2004; Tarazona et al., 2003). The diversity of marine molluscs in this region is composed of species of tropical, subtropical and Antarctic origin, resulting in a rich endemic fauna and a high number of species (Ramírez et al., 2003; Tarazona et al., 2003). Although many species have been compiled and reported (see reviews in Alamo \& Valdivieso, 1997; Ramírez et al., 2003), the information is often skewed towards reports of macro gastropods, bivalves and cephalopods with distinctive morphological characteristics (e.g. shell, valves or peaks) while some groups such as nudibranchs (Gastropoda, Nudibranchia) have received very little attention and the available information is scarce.

Even though their colourful and striking morphology may be appealing for taxonomic work, the current status of the number of species and distribution of nudibranchs on the coast of Peru is restricted to a few locations with the main research emphasis having been focused on the northern coast. Nakamura (2006, 2007) registered a total of 54 species on the Peruvian coast

Corresponding author:

R.A. Uribe

Email: uribealzamora@gmail.com with 17 species recorded exclusively in the northern area $\left(\sim 3^{\circ} \mathrm{S}\right)$. Recently a new species of the genus Corambe has been described in the northern region (Martynov et al., 2011). Clearly, much more information from the central and southern coast (approximately $2500 \mathrm{~km}$ of coastline) is necessary for fully understanding the diversity and composition of nudibranchs in this highly productive upwelling ecosystem.

Spurilla neapolitana Delle Chiaje, 1823 is a nudibranch of the Aeolidiidae family with circumtropical distribution, thriving from the middle intertidal down to $80 \mathrm{~m}$ depth (Reed \& Mikkelsen, 1987). This species can be found in rocky substratum among crevices and underneath boulders (Bertsch \& Kerstitch, 1984), soft bottoms and kelp forest invertebrate communities (Rodriguez et al., 2003). It preys on sea anemones, consuming the oral disc and tentacles (García \& Cervera, 1985; Schlesinger et al., 2009) and also serves as a prey item of crustaceans, star fish and a few predatory gastropods (Reed \& Mikkelsen, 1987).

In this study we report the presence of $S$. neapolitana for the first time in Bahía Ferrol, a location within the HCUE of the central coast of Peru. A brief description of the external morphology is presented.

\section{MATERIALS AND METHDDS}

Two specimens of Spurilla neapolitana were collected in November 2009 at Hueco de la Vela (09 $04^{\prime} \mathrm{S} 78^{\circ} 35^{\prime} \mathrm{W}$ ) within Bahía Ferrol on the central coast of Peru (Figure 1). The samples were taken during a stock assessment of the scallop Argopecten purpuratus (Lamarck, 1819) population, conducted by IMARPE (Instituto del Mar del Peru, 


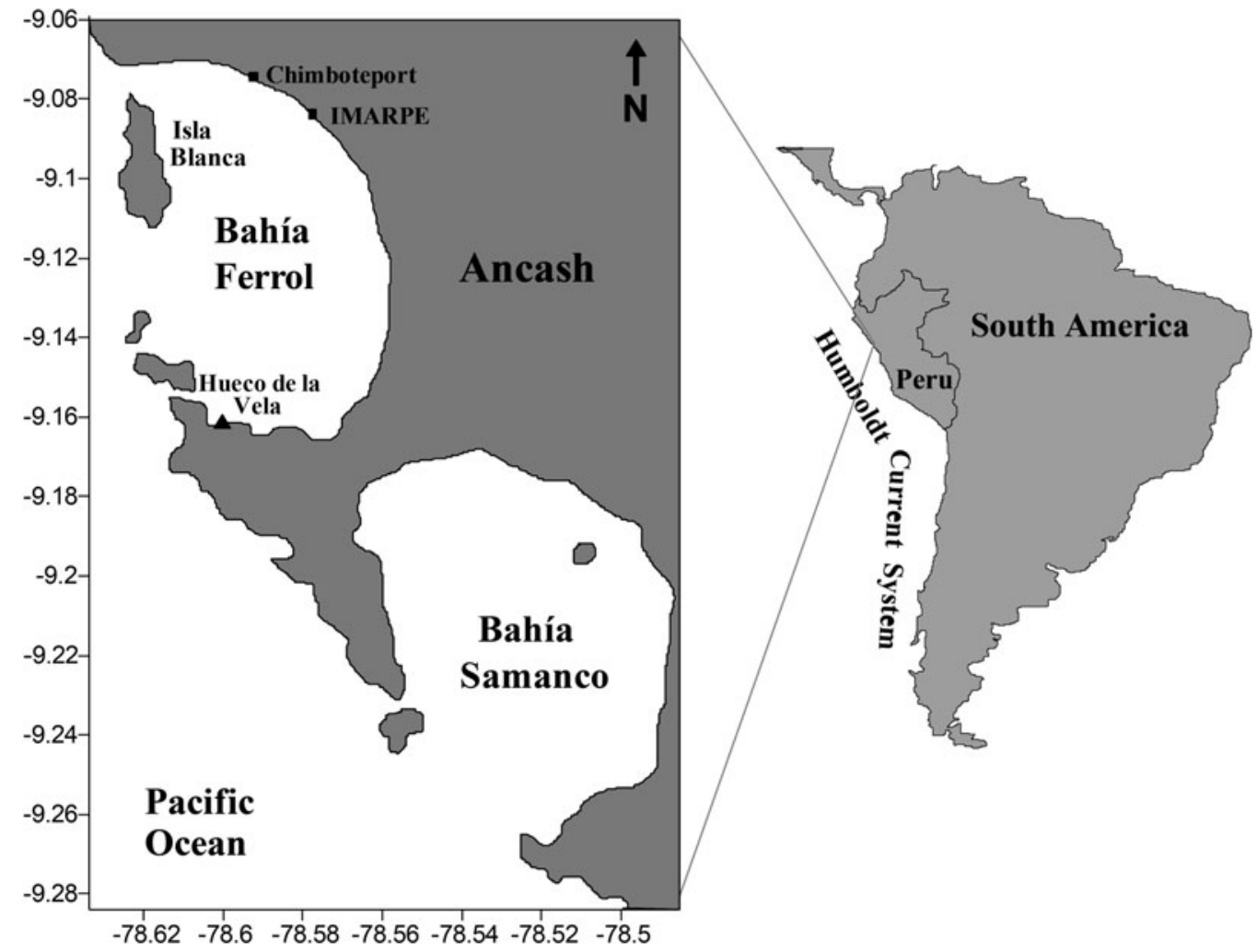

Fig. 1. Map of Bahia Ferrol, located at the coast of Ancash, Peru. The triangle indicates the location were S. neapolitana were collected.

Peruvian Sea Research Institute). During the assessment the scallop population size is surveyed using randomly distributed sampling points $(\mathrm{N}=15)$ covering the entire seabed area $\left(\sim 280,000 \mathrm{~m}^{2}\right)$. At each sampling point a hooka diver placed a $1-\mathrm{m}^{2}$ quadrate on the bottom, observing the epibenthos inside the quadrate and the surrounding marked area, and then all the biota within the quadrate was collected and stored in plastic bags. In addition, depth was recorded and water samples for measurements of bottom temperature and dissolved oxygen were taken using a Niskin bottle. Individuals of S. neopolitana were observed in the surrounding area outside a sampling quadrate and collected separately. In the laboratory, live animals were maintained in a seawater aquarium in order to take photographs and make observations. Length measurements were taken with a caliper of $0.1-\mathrm{mm}$ precision and wet weight $(0.01 \mathrm{~g})$. Thereafter, the samples were fixed in $10 \%$ formalin solution and preserved in $70 \%$ alcohol. The sample was deposited in the marine specimens collection of the Laboratorio Costero de Chimbote (IMARPE laboratory no. 4.11.2009.MN1-LCCH).

\section{RESULTS}

\section{Habitat}

Spurilla neapolitana was found at $10 \mathrm{~m}$ depth with a water temperature of $15.7^{\circ} \mathrm{C}$ and $1.50 \mathrm{ml} / \mathrm{l}$ dissolved oxygen. The sediment comprised a mix of sand-gravel and shell pieces. The epibenthic community was dominated by the tube building polychaete Diopatra rizhoicola, red algae Rhodymenia sp., scallops Argopecten purpuratus and predatory crabs
Platyxanthus cokeri and Cancer setosus. In addition, small white anemones were observed and likely served as food for the sea slug (Bigger, 1980; García \& Cervera, 1985).

\section{Diagnosis}

The total length of the adult S. neapolitana was $85.5 \mathrm{~mm}$ and weighed $3.58 \mathrm{~g}$. The body is long with an intense orange colouring and white spots along the dorsal line (Figure 2A). Distinguishing this species (García \& Cervera, 1985; Domínguez et al., 2008) are the perfoliate rhinophores with 18 lamella horizontally alternating, one over the other. The general yellowish and light-brown coloration gives a dark appearance to the rhinophores (Figure $2 \mathrm{~B}$ ). Oral tentacles are thin, short and rounded, translucent with white tips deployed at both sides of the mouth (Figure $2 \mathrm{~B}$ ). The oral palps are rough. The cerata are long, gross and flat closer to the tip (Figure $2 \mathrm{~B}$ ). There are between eight and 12 ceratal arcs in each side of the body. The second ceratal arc shows 60 cerata at each side. Larger cerata are located in the middle of the arc while short cerata are present in the arc extreme. The apex of the cerata is curved towards the dorsal middle line. Cerata are translucent with white spots. The brownish digestive gland can be observed through the cerata (Figure $2 \mathrm{~B}$ ). The pericardium is located in the first and second ceratal group (García \& Cervera, 1985). The genital opening is on the right side of the body located below the first arc and the anus is located below the second group. The tail is short and translucent. The foot is wide, of lightorange colour. The hepatic branches look like fine trusses of dark colour. The coloration of S. neapolitana varies depending on the habitat and feeding type and food composition, 


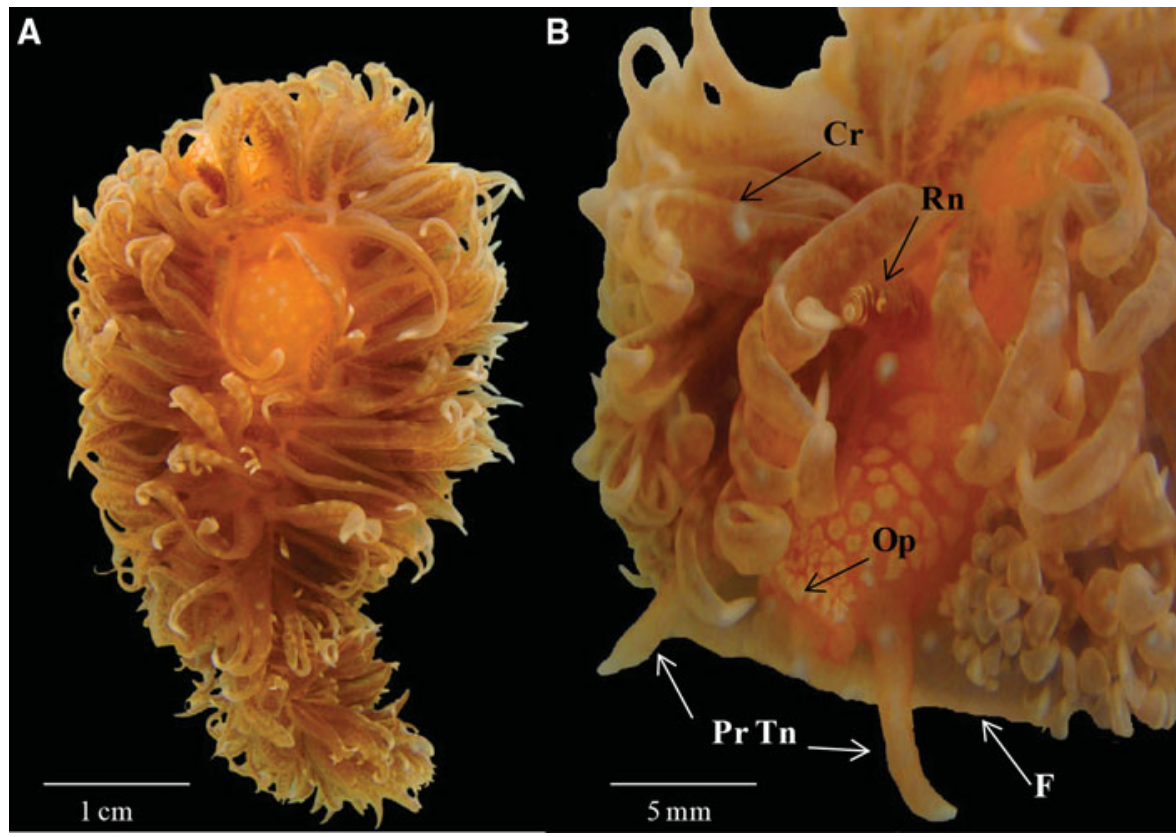

Fig. 2. Spurilla neapolitana (A) Dorsal view; (B) anterior view. Cr: cerata, Rn: rhinophore, Op: oral palps, Pr Tn: propodial tentacles, F: foot.

however, the yellow-orange and white dotted pattern is distinctive in most of the reported individuals (Haefelfinger, 1969; García \& Cervera, 1985; Just \& Edmunds, 1985).

\section{DISCUSSION}

\section{Taxonomic remarks}

The genera Spurilla, Berghia and Aeolidiella are distinctive for having more cerata compared with other nudibranchia species (Gosliner et al., 2007). Spurilla neapolitana shows external similarities to S. chromosoma (Cockerell \& Eliot, 1905; Rudman, 1999). Both species show the dorsal part with a white dotted pattern, curved and translucent cerata with dark colouring and a white dotted pattern (García \& Cervera, 1985). However, S. chromosoma shows cerata lines in the anterior region of the body and rinophores with few lamella diagonally arranged, while $S$. neapolitana shows ceratal arcs in a horseshoe shape and the perfoliated rinophore are completed transversal (Domínguez et al., 2008).

\section{Distributional remarks}

Spurilla neapolitana (Delle Chiaje, 1841) shows a circumtropical distribution (Bertsch, 2010) and it has been reported in several areas in the Mediterranean Sea, eastern/western Atlantic Ocean and a few places in the Pacific Ocean (Table 1). Despite its wide distribution, S. neapolitana is often reported thriving in warm waters or locations with strong seasonal changes in the oceanographic conditions. Here we report this species in the central coast of Peru, a region that even though it is at low latitude and closer to the equator, the presence of a cold, nutrient rich upwelling process resembles more a temperate region. Interestingly, the diversity of nudibranchs along the Peru-Chile coastline has been better described in ecotone areas such as the transition from the cold upwelling to the warm Equatorial province in northern Peru (Nakamura, 2006, 2007) or in the transition from the upwelling to the Magellanic province in southern Chile (Schrödl, 2003). Whether transitional areas are more diverse in terms of nudibranch species is still a

Table 1. World distribution of Spurilla neapolitana Delle Chiaje, 1841, including sampling zone of the material study.

\begin{tabular}{|c|c|c|}
\hline Region & Locality & Reference \\
\hline \multirow{7}{*}{$\begin{array}{l}\text { Mediterranean } \\
\quad \text { Sea }\end{array}$} & Estrecho de Gibraltar & Ros (1975) \\
\hline & Cataluña and Baleaes, Spain & Ros (1975) \\
\hline & Barcelona, Spain & García \& Cervera (1985) \\
\hline & Tarento, Italy & García \& Cervera (1985) \\
\hline & Turkey & Marcus \& Marcus (1966) \\
\hline & Adriatic Sea & Marcus \& Marcus (1966) \\
\hline & Israel coast & Schlesinger et al. (2009) \\
\hline \multirow[t]{6}{*}{ Eastern Atlantic } & Tarifa and Huelva, Spain & García \& Cervera (1985) \\
\hline & France & Just \& Edmunds (1985) \\
\hline & Morocco & Just \& Edmunds (1985) \\
\hline & Senegal & Marcus \& Marcus (1962) \\
\hline & $\begin{array}{l}\text { Cabo Verde and Canarias } \\
\text { Island }\end{array}$ & Marcus \& Marcus (1962) \\
\hline & Guinea Gulf & Marcus \& Marcus (1966) \\
\hline \multirow[t]{7}{*}{ Western Atlantic } & Laguna Indian River & Mikkelsen et al. (1995) \\
\hline & Florida & $\begin{array}{l}\text { Reed \& Mikkelsen } \\
\quad(1987)\end{array}$ \\
\hline & Golfo de México & Marcus \& Marcus (1966) \\
\hline & Jamaica & Marcus \& Marcus (1966) \\
\hline & Tayrona, Colombia & Ardila et al. (2007) \\
\hline & $\begin{array}{l}\text { Río de Janeiro and Bahía, } \\
\text { Brazil }\end{array}$ & Domínguez et al. (2008) \\
\hline & Argentina & Schrödl (2003) \\
\hline \multirow[t]{5}{*}{ Pacific } & Oahu, Hawaii & Gosliner (1979) \\
\hline & $\begin{array}{l}\text { Baja California del Sur, } \\
\text { Mexico }\end{array}$ & $\begin{array}{l}\text { Bertsch \& Kerstitch } \\
\quad(1984)\end{array}$ \\
\hline & Golfo de California, Mexico & Bertsch (1979) \\
\hline & Punta Arenas, Costa Rica & Rodríguez et al. (2003) \\
\hline & Ancash, Perú & This study \\
\hline
\end{tabular}


matter of further study, our knowledge about nudibranchs diversity will improve when more information coming from the core area of the upwelling system is available. The record of $S$. neapolitana adds support to the predictions of Gosliner (1991) and Schrödl (2003) for findings of more nudibranch species in the region.

While this report extends the distribution range of $S$. neopolitana into the south-east Pacific, it is difficult to determine the source location of this species. Research effort on nudibranchs is poor in the area, so it possible that this species and others may be overlooked during surveys of benthic organisms. However, there are other processes influencing the marine benthic biota composition in the region that must be taken into account. During strong El Niño events, many mollusc species extend their distributional range towards high latitudes due to the intrusion of equatorial transporting larvae and adults from the equator down to central and southern Chile (e.g. Paredes et al., 1998, 2004). Some species may stay even longer at specific locations with suitable conditions for survival after El Niño events (e.g. Ashton et al., 2008). During upwelling conditions, larvae transport from high latitudes towards the equator is due to the predominant northward direction of the Humboldt Current (Tarazona et al., 2003). Also, a great amount of invertebrates including nudibranchs can be transported through rafting (Astudillo et al., 2009) which may explain the local presence of several species with disjoint geographical distribution (e.g. Castilla \& Guiñez, 2000; Pacheco \& Laudien, 2008).

\section{ACKNDWLEDGEMENTS}

We thank Aldo Indacochea, Lucas Cervera and Jesús Troncoso for the taxonomic advice. Javier Uribe Balbín is thanked for the photographic support. Michael Schrödl provided helpful comments on an early version of this manuscript. Carrie Auld kindly revised the English of this manuscript. Jesús Tronsco is thanked for encouraging us to document this finding. Funding during scallop population assessment was provided by IMARPE. R.A.U. is supported by Programa MECE2 Educación Superior/MECESUP, Proyecto MECE ANTo711. A.S.P.'s research is supported by FONDECYT grant no. 3100085 .

\section{REFERENCES}

Alamo V. and Valdivieso V. (1997) Lista sistemática de moluscos marinos del Perú. Boletin. Instituto del Mar del Perú-Callao. Volumen Extraordinario, $205 \mathrm{pp}$.

Ardila N., Baez D. and Valdés A. (2007) Babosas y liebres de mar (Mollusca: Gastropoda: Opisthobranchia) de Colombia. Biota Colombiana 8, 185-197.

Ashton T., Riascos J. and Pacheco A. (2008) First record of Cymatium keenae Beu, 1970 (Mollusca: Ranellidae) from Antofagasta Bay, northern Chile, in connection with El Niño events. Helgoland Marine Research 62, 107-110.

Astudillo J.C., Bravo M., Dumont C.P. and Thiel M. (2009) Detached aquaculture buoys in the SE Pacific: potential dispersal vehicles for associated organisms. Aquatic Biology 5, 219-231.

Bertsch H. (1979) Tropical faunal affinities of opisthobranchs from the Panamic province (eastern Pacific). Nautilus 93, 57-61.
Bertsch H. (2010) Biogeography of Northeast Pacific opisthobranchs: comparative faunal province studies between point Conception, California, USA, and Punta Aguja, Piura, Perú. In Rangel L.J., Gamboa J., Arriaga S. and Contreras W.M. (eds) Perspectivas en Malacologia Mexicana. Tabasco, Mexico: Universidad Juárez Autónoma de Tabasco, pp. 219-259.

Bertsch H. and Kerstitch A. (1984) Distribution and radular morphology of various nudibranchs (Gastropoda: Opisthobranchia) from the Gulf of California, México. Veliger 26, 264-273.

Bigger C. (1980) Interspecific and intraspecific acrorhagial aggressive behavior among sea anemones: recognition of self and not-self. Biological Bulletin. Marine Biological Laboratory, Woods Hole 159, 117-134.

Castilla J.C. and Guiñez R. (2000) Disjoint geographical distribution of intertidal and nearshore benthic invertebrates in the Southern Hemisphere. Revista Chilena de Historia Natural 73, 585-603.

Chavez F.P., Bertrand A., Guevara-Carrasco R. and Soler P. (2008) The northern Humboldt Current System: brief history, present status and a view towards the future. Progress in Oceanography 79, 95-105.

Domínguez M., Troncoso J. and García F. (2008) The family Aeolidiidae Gray, 1827 (Gastropoda: Opisthobranchia) from Brazil, with a description of a new species belonging to the genus Berghia Trinchese, 1877 . Zoological Journal of the Linnean Society 153, 349-368.

García J.C. and Cervera J.L. (1985) Revisión de Spurilla neapolitana delle Chiaje, 1823 (Mollusca: Nudibranchiata). Journal of Molluscan Studies $51,138-156$.

Gosliner T. (1979) The systematics of the Aeolidacea (Nudibranchia: Mollusca) of the Hawaiian Islands, with descriptions of two new species. Pacific Science 33, 37-77.

Gosliner T. (1991) The opisthobranch gastropod fauna of the Galapagos Islands. In Matthew J.J. (ed.) Galapagos marine invertebrates: taxonomy, biogeography, and evolution in Darwin's Islands (Topics in Geobiology). New York: Plenum Press, pp. 281-305.

Gosliner T., González-Duarte M. and Cervera L. (2007) Revision of the systematics of Babakina Roller, 1973 (Mollusca: Opisthobranchia) with the description of a new species and a phylogenetic analysis. Zoological Journal of the Linnean Society 151, 671-689.

Haefelfinger H. (1969) Pigment and pattern in marine slugs. Nautilus (Basle) 5, 3-5.

Just H. and Edmunds M. (1985) North Atlantic nudibranchs (Mollusca) seen by Henning Lemche. Ophelia, International Journal of Marine Biology 2, 1-170.

Marcus E. and Marcus E. (1962) Opisthobranchs from Florida and the Virgin Islands. Bulletin of Marine Science 12, 450-488.

Marcus E. and Marcus E. (1966) Opisthobranchs from tropical West Africa. Studies in Tropical Oceanography 4, 152-208.

Martynov A., Brenzinger B., Hooker Y. and Schrödl M. (2011) 3-D anatomy of a new tropical Peruvian nudibranch gastropod species, Corambe mancorensis, and novel hypotheses on dorid gill ontogeny and evolution. Journal of Molluscan Studies 77, 129-141.

Mikkelsen P., Mikkelsen P. and Karlen D. (1995) Molluscan biodiversity in the Indian River Lagoon, Florida. Bulletin of Marine Science 57, 94127.

Nakamura K. (2006) New records of opisthobranch mollusks from the Guayaquil marine ecoregion: northern Peru. The Festivus 38, 75-83.

Nakamura K. (2007) Benthonic opisthobranch species (Mollusca: Gastropoda) from the northern Peruvian coast. Revista Peruana de Biología 13, 255-257.

Pacheco A. and Laudien J. (2008) Dendropoma mejillonensis sp. nov. a new species of vermetid (Caenogastropoda) from northern Chile. Veliger 50, 219-224. 
Paredes C., Cardoso F. and Tarazona J. (2004) Temporary distribution of mollusks and tropical crustaceans in the Peruvian Province and its relation with the events El Niño. Revista Peruana de Biologia 12, $213-218$.

Paredes C., Tarazona J., Canahuire E., Romero L., Cornejo O. and Cardoso F. (1998) Presence of tropical mollusks from the Panamanian province in the central coast of Peru and relation with the events 'El Niño'. Revista Peruana de Biologia 5, 123-128.

Ramírez R., Paredes C. and Arenas J. (2003) Moluscos del Perú. Revista de Biología Tropical 51, 225-284.

Reed J.K. and Mikkelsen P.M. (1987) The molluscan community associated with the scleractinian coral Oculina varicosa. Bulletin of Marine Science 40, 99-131.

Rodríguez L., Vargas R. and Cortés J. (2003) Biodiversidad marina de Costa Rica: Gastrópodos (Mollusca: Gastropoda) de la costa Caribe. Revista de Biología Tropical 51, 305-399.

Ros J. (1975) Catálogo provisional de Opistobranquios (Gastrópoda: Euthyneura) de las costas Ibéricas. Miscelánea Zoológica 5, 21-51.

Rudman W.B. (1999) Spurilla neopolitana. Sea Slug Forum. www.seaslug forum.net (accessed March 2011).
Schlesinger A., Goldshmid R., HadWeld M., Kramarsky-Winter E. and Loya Y. (2009) Laboratory culture of the aeolid nudibranch Spurilla neapolitana (Mollusca, Opisthobranchia): life history aspects. Marine Biology 156, 753-761.

Schrödl M. (2003) Sea slugs of southern South America. Systematics, biogeography and biology of Chilean and Magellanic Nudipleura (Mollusca: Opistobranchia). Hackenheim, Germany: Conchbooks.

and

Tarazona J., Gutiérrez D., Paredes C. and Indacochea A. (2003) Overview and challenges of marine biodiversity research in Peru. Gayana 67, 206-231.

\section{Correspondence should be addressed to:}

\section{R.A. Uribe}

Programa de Doctorado en Ciencias Aplicadas Mención Sistemas Marinos Costeros

Instituto de Investigaciones Oceanológicas

Universidad de Antofagasta

Avenida Angamos 601, PO Box 170

Antofagasta, Chile

email: uribealzamora@gmail.com 